\title{
Ethical guidelines for military-based health research: An unmet need in Africa?
}

\author{
J Nwobegahay, ${ }^{1,2} \mathrm{PhD} ;$ J Ali, ${ }^{2}$ JD; D Ter Goon, ${ }^{3} \mathrm{PhD} ; \mathbf{A}$ A Hyder, ${ }^{4} \mathrm{MD}, \mathrm{MPH}, \mathrm{PhD}$ \\ ${ }^{1}$ Yaounde Military Hospital, Yaoundé, Cameroon; and Military Health Research Center (CRESAR), Yaoundé, Cameroon \\ ${ }^{2}$ Fogarty African Bioethics Training Program, Johns Hopkins Berman Institute of Bioethics, Baltimore, USA \\ ${ }^{3}$ Department of Health Sciences, University of Fort Hare, Alice, South Africa \\ ${ }^{4}$ Johns Hopkins Bloomberg School of Public Health, Baltimore, USA
}

Corresponding author: D Ter Goon (daniel.goon2013@yahoo.com)

Background. Achieving the highest standards of ethics in military health research is a challenging but crucial undertaking. The military environment is complex and African military health professionals struggle to maintain a balance between ethics and military ethos. The objective of this paper is to explore research ethics guidelines by reviewing 10 examples for their application to the military context, and describe the need for guidance in military research ethics in sub-Saharan Africa.

Method. To achieve this, five prominent international research ethics guidelines and five African guidelines were selected. Thereafter, designed topics were used in analysing them for their strengths and weaknesses in providing protection for military research participants. Results. Out of the five international guidelines reviewed, only the Council for International Organization of Medical Sciences (CIOMS) mentions the 'armed forces'. Similarly, the only African national guideline that specifically mentions the 'armed forces' is the Ugandan national guideline.

Conclusions. We concluded that national and international guidelines for human subject research may be too general and not suitable for research with military populations. There is a need for additional guidance in research ethics for military health research in sub-Saharan Africa.

S Afr J BL 2015:8(2):11-16. DOI:10.7196/SAJBL.433

The military has increasingly become a site for research. In Africa, for instance, bilateral and multilateral military alliances have opened the way for collaborative health research programmes between and within various countries. For example, the non-profit Research Triangle Institute has collaborated with the US Naval Health Research Center of the US Department of Defense HIV/AIDS Prevention Program (DHAPP) to develop and implement of an HIV behavioural health surveillance programme for the armed forces in Mozambique and Uganda. ${ }^{[1]}$ In the Central African sub-region, DHAPP also provides technical and financial assistance to national militaries for the implementation of HIV prevention and surveillance activities. In the Republic of South Africa (SA), the South African Military Health Service and DHAPP are involved in a collaborative research project known as Phidisa, which also involves the US National Institute of Health. ${ }^{[2]}$

Given this trend towards increased research collaboration with the military, a critical evaluation of the ethics standards for research with military populations is necessary. While many scholarly and practical efforts have yielded significant progress towards greater protection for research participants in general, relatively little attention has been paid to ethical guidelines for military researchers in developing countries. Military health personnel and soldiers work in complex cultural environments that often contrast with civilian life. ${ }^{[1]}$ While international codes of ethics generally prescribe complete loyalty to patients, military health professionals have the duty to both support military objectives and promote the health of individuals. ${ }^{[3]}$ The problem of dual loyalty is also common in settings such as occupational health and forensic services, and these tensions could result in ethical and human rights consequences for both soldiers and civilians. ${ }^{[4]}$ The issue of dual loyalty could be a particular problem in military medical service, especially when there has been no formal ethical theory specific to military physicians. ${ }^{[4]}$

Additionally, some research populations are particularly vulnerable and need special protection. These include those who cannot give or refuse consent for themselves and those who may be vulnerable to coercion or undue influence. Soldiers live in camps and barracks, and they are easily accessible as a result of proper internal organisation. Decisions and orders from superior members of the armed forces could be easily applied to the entire troop because of the strong notion of respect for hierarchy and orders.

As the military are, by nature, institutions of global power and influence, research with military populations should be subject to the rules, principles, and guidelines that broadly inform international research ethics. However, it is important to acknowledge that standard protections may be insufficient for military populations where, for instance, a culture of absolute obedience to authorities may potentially conflict with the right to patient and participant autonomy in health and research decisions. ${ }^{[5]}$

This paper explores the extent to which current international and African research ethics guidelines address military health research and describes the need for research ethics guidelines for the military in sub-Saharan Africa. It reviews 10 prominent examples of existing international and African ethics guidelines to assess content that addresses research with military populations. The paper concludes by 
exploring the need for alternative (local and population-specific) guidelines that protect the populations involved in African military human subject research.

\section{Methods \\ Ethical considerations}

Ethical clearance for this study was obtained from the National Ethics Committee of Cameroon and the Institutional Review Board (IRB) of the Johns Hopkins Bloomberg School of Public Health (JHSPH).

\section{Review of selected research ethics guidelines}

A convenience sample of five prominent international guidelines and five African guidelines were reviewed for particular application to human subject research within the military. International guidelines were reviewed to determine their relevance to human subject health research within the military, with particular attention to whether the international guidelines make mention of or address, the military directly. The strength or weakness of the guidelines was further determined.

African national guidelines were reviewed to determine:

- The usefulness of national guidelines for research within the ranks

- Soldiers' participation in research vis-à-vis promotion and career opportunities

- Payment of military personnel for participating in research, and

- The relationship between senior military physicians and subordinate soldiers, during and after research.

The criteria used in the selection of guidelines are presented in Table 1. The following international research ethics guidelines were reviewed: the Nuremberg Code, the Declaration of Helsinki, the Belmont Report, the guidelines for ethics committees that review biomedical research, and the Council for International Organisation of Medical Sciences (CIOMS) guidelines.

Similarly, five national guidelines on health research ethics were obtained from African countries: guidelines on ethics for health research in Tanzania, the national code for health research ethics for Nigeria, Ugandan national guidelines for research involving humans as research participants, guidelines on ethics for medical research in SA and the guidelines for health research in Zimbabwe.
The guidelines were reviewed and relevant information was extracted and compiled into tables. The guidelines were screened for any language that directly or indirectly concerned populations in the armed forces and sections or references to health research on or by the military. These sections were then analysed for their strengths and weaknesses in providing protection to military populations involved in health research.

The article then uses these examples to conceptually demonstrate the need for further guidance in this area.

\section{Results \\ International guidelines and military research}

The Nuremberg Code was written in 1947 by the Nuremberg Military Tribunals in response to the atrocities committed by Nazi doctors and medical scientists, ${ }^{[6]}$ and became the prototype of many later codes of ethics intended to ensure that research involving human subjects is carried out in an ethical manner. ${ }^{[7]}$ Despite originating as a response to war crimes and crimes against humanity conducted by military physicians, there are no specific sections of the 10-point document that address the military (Table 2). However, it clearly brought forth the requirement for voluntary informed consent of the research subjects and points out the fact that riskbenefit analysis is important in human subject health research while unnecessary pain and suffering should be avoided.

The Declaration of Helsinki was adopted by the 18th World Medical Association (WMA) in 1964 and was recently amended for the ninth time by the 64th WMA General Assembly, Fortaleza, Brazil in 2013..$^{[8]}$ This is the first postWorld War II health research guideline that includes a section concerning 'vulnerable populations', though no reference is specifically made to the military (Table 2). In paragraph 9 of the introduction, the declaration states that 'some research populations are particularly vulnerable and need special protection.' It further states that: 'These include those who cannot give or refuse consent for themselves and those who may be vulnerable to coercion or undue influence.' However, paragraph 9 does not define 'vulnerable populations', and fails to clearly define the kind of special protection needed to protect vulnerable populations. The Declaration of Helsinki does not directly address soldiers, but it could still be a useful document to guide military physicians during research in military populations. However, some military physicians could find it difficult to apply paragraph 6 which states that: 'In medical research involving human subjects, the well-being of the individual research subject must take precedence over all other interests'. Paragraph 6 potentially conflicts with basic military culture which considers the interests of the military as supreme. During basic military training, soldiers (including military physicians) are taught that the interests of the military as an institution is always [and must be considered at all times] more important than the interests of the individual soldier. Paragraph 6 could, therefore, be a weakness in using the declaration of Helsinki in military health research.

The Belmont Report, written in 1979, addressed some of the limitations of previous

Table 1. Criteria used in the selection of guidelines

\begin{tabular}{|c|c|}
\hline \multicolumn{2}{|l|}{ A. African guidelines } \\
\hline Inclusion criteria & Exclusion criteria \\
\hline 1. Must be from a country in sub-Saharan Africa & 1. Not from sub-Saharan Africa \\
\hline 2. Must have a national character & 2. Not used throughout the country \\
\hline 3. Guideline for human subject health research & 3. Guideline not for human subject health research \\
\hline 4. Guideline readily available on the internet & 4. Not available on the internet \\
\hline 5. Guideline published between 2000 and 2009 & 5. Guideline published before 2000 \\
\hline \multicolumn{2}{|l|}{ B. International guidelines } \\
\hline Inclusion criteria & Exclusion criteria \\
\hline 1. Guideline for human subject health research & 1. Not for use with human subject health research \\
\hline 2. Has global use & 2. Restricted use \\
\hline 3. Guideline readily available on the internet & 3. Not available on the internet \\
\hline $\begin{array}{l}\text { 4. Must be referenced in at least one of the } \\
\text { African national guidelines already selected } \\
\text { for this study }\end{array}$ & 4. Not referenced in any of the African guidelines \\
\hline
\end{tabular}


guidelines ${ }^{[9]}$ The report was written by the US National Commission for the Protection of Human Subjects of Biomedical and Behavioral Research. It was meant to provide broad ethical principles as an analytical framework to guide the resolution of ethical problems arising from research involving human subjects. ${ }^{[7]}$ The Belmont Report does not directly address the military in any of its sections. However, it too references 'vulnerable populations' in its discussion of informed consent, risk-benefit assessment, and the selection of subjects for research (Table 2). The section on voluntariness in informed consent states that: 'an agreement to participate in research constitutes a valid consent only if voluntarily given'.9] This section of the report further states that 'unjustifiable pressures usually occur when persons in position of authority or commanding influence - especially where possible sanctions are involved - urge a course of action for a subject. ${ }^{\prime[9]}$ This language may have implications for military health research; however, the use of the word 'unjustifiable' significantly lowers the level of protection. The report falls short of making clear what sort of pressure might be justifiable, and it is possible that pressure might be considered 'justifiable' in some military contexts, such as in times of combat.

Furthermore, the section concerning the selection of subjects could be applied to military researchers. It states that certain groups, such as racial minorities, the economically disadvantaged, the very sick, and the institutionalised may continually be sought as research subjects, owing to their ready availability in settings where research is conducted.
Given their dependent status and their frequently compromised capacity for free consent, they should be protected against the danger of being involved in research solely for administrative convenience, or because they are easy to manipulate. Such extra protections may also be warranted in the military where soldiers are relatively restrained in their movement and limited in their capacity to make particular decisions. Nevertheless, guidance does not indicate whether, and under what conditions, the operational interests of the military can override those of the individual, in research.

The World Health Organization (WHO) operational guidelines for ethics committees that review biomedical research, published in 2000, were developed to support ethics committees globally. ${ }^{[10]}$ The WHO guidelines have an African origin as the first draft of these guidelines were discussed at a workshop for members of African Ethical Review Committees organised by the WHO special programme for training in Tropical Diseases and Research (WHO TDR) and the African Malaria Vaccine Testing Network (AMVTN) in Arusha, Tanzania, on 5 November 1999. The draft was subsequently presented to an interim meeting of the Forum for Ethical Review Committees in the Asian and Western Pacific Regions in Bethesda, Maryland, USA, on 9 November 1999.

The guidelines take into consideration that a large proportion of biomedical research is now collaborative, often involving investigators or donors from high-income nations working in lowincome contexts. These guidelines do not address the military directly,

\section{Table 2. Review of selected international research ethics guidelines for relevance to military health research}

\begin{tabular}{|c|c|c|c|c|c|}
\hline No. & $\begin{array}{l}\text { Title of } \\
\text { guideline }\end{array}$ & $\begin{array}{l}\text { Year of } \\
\text { publication }\end{array}$ & Source & $\begin{array}{l}\text { Specific sections/chapters } \\
\text { concerning the military }\end{array}$ & $\begin{array}{l}\text { Discussion of particular } \\
\text { military research issues* }\end{array}$ \\
\hline 1. & $\begin{array}{l}\text { The Nuremberg } \\
\text { Code }\end{array}$ & 1947 & $\begin{array}{l}\text { The Department of Health, } \\
\text { Education, and Welfare, Office of } \\
\text { the Secretary, Protection of Human } \\
\text { Subjects of the US Government. } \\
\text { http://ohsr.od.nih.gov/guidelines/ } \\
\text { nuremberg.html }\end{array}$ & $\begin{array}{l}\text { None; however, it was written } \\
\text { in response to the atrocities } \\
\text { Nazi doctors and medical } \\
\text { scientists had committed on } \\
\text { prisoners in concentration } \\
\text { camps }\end{array}$ & None \\
\hline 2. & $\begin{array}{l}\text { The Declaration } \\
\text { of Helsinki }\end{array}$ & 2000 & $\begin{array}{l}\text { WMA http://www.wma.net/e/ } \\
\text { policy/b3.htm }\end{array}$ & $\begin{array}{l}\text { This guideline does not } \\
\text { address the military }\end{array}$ & None \\
\hline 3. & $\begin{array}{l}\text { The Belmont } \\
\text { Report }\end{array}$ & 1979 & $\begin{array}{l}\text { The Department of Health, } \\
\text { Education, and Welfare, Office of } \\
\text { the Secretary, Protection of Human } \\
\text { Subjects of the US Government. } \\
\text { http://ohsr.od.nih.gov/guidelines/ } \\
\text { belmont.html }\end{array}$ & $\begin{array}{l}\text { This guideline partly } \\
\text { addresses the military in part } \\
\text { C, where it makes reference to } \\
\text { vulnerable populations in all } \\
\text { three of its requirements }\end{array}$ & None \\
\hline 4. & $\begin{array}{l}\text { Guidelines } \\
\text { for Ethics } \\
\text { Committees } \\
\text { that Review } \\
\text { Biomedical } \\
\text { Research }\end{array}$ & 2000 & $\begin{array}{l}\text { WHO } \\
\text { http://www.searo.who.int/LinkFiles/ } \\
\text { RPC_Operational_Guidlines_Ethics. } \\
\text { pdf }\end{array}$ & $\begin{array}{l}\text { None, however, it can guide } \\
\text { militaries in establishing } \\
\text { research ethics committees }\end{array}$ & None \\
\hline 5. & $\begin{array}{l}\text { The Council for } \\
\text { International } \\
\text { Organization } \\
\text { of Medical } \\
\text { Sciences }\end{array}$ & 2002 & $\begin{array}{l}\text { The Council for International } \\
\text { Organizations of Medical Sciences. } \\
\text { http://www.cioms.ch/frame_- } \\
\text { guidelines_nov_2002.htm }\end{array}$ & $\begin{array}{l}\text { This guideline directly } \\
\text { addresses the military } \\
\text { This is the only international } \\
\text { guideline examined in this } \\
\text { review which specifically makes } \\
\text { mention of the armed forces in } \\
\text { guideline } 13\end{array}$ & Yes \\
\hline
\end{tabular}


nor do they discuss setting up research ethics committees in military establishments. However, the statement that: 'the Guidelines should be used by national and local bodies in developing, evaluating, and progressively refining standard operating procedures for the ethical review of biomedical research' could be applicable to militaries that wish to establish their own guidelines and review boards (Table 2).

The CIOMS published its revised International Ethical Guidelines for Biomedical Research Involving Human Subjects in 2002. ${ }^{[1]}$ The revised CIOMS guidelines have a section concerning members of the Armed Forces (Table 2). Guideline 13 concerns research involving vulnerable persons and specifies that: '[s]pecial justification is required for inviting vulnerable individuals to serve as research subjects and, if they are selected; the means of protecting their rights and welfare must be strictly applied'. It further states that: '[t]he quality of the consent of prospective subjects who are junior or subordinate members of a hierarchical group requires careful consideration, as their agreement to volunteer may be unduly influenced, whether justified or not, by the expectation of preferential treatment if they agree, or by fear of disapproval or retaliation if they refuse. Examples of such groups are medical and nursing students, subordinate hospital and laboratory personnel, employees of pharmaceutical companies and members of the armed forces and police. ${ }^{[11]} \mathrm{CIOMS}$ is the only international guideline examined in this review that specifically mentions the armed forces.

\section{African national ethics guidelines and military research}

The national ethics guidelines of Uganda, Nigeria, SA, Tanzania, and Zimbabwe were selected for review (Table 3). Uganda's revised

Table 3. Review of selected national research ethics guidelines in Africa for relevance to military health research

\begin{tabular}{|c|c|c|c|c|c|c|}
\hline No. & Title & $\begin{array}{l}\text { Year of } \\
\text { Publication }\end{array}$ & Source & $\begin{array}{l}\text { Specific sections/ } \\
\text { chapters concerning the } \\
\text { military }\end{array}$ & $\begin{array}{l}\text { Discussion of particular } \\
\text { military research } \\
\text { issues* }\end{array}$ & $\begin{array}{l}\text { Presence of any } \\
\text { other rules which } \\
\text { are specific for } \\
\text { the military } \dagger\end{array}$ \\
\hline 1. & $\begin{array}{l}\text { National } \\
\text { Guidelines } \\
\text { for Research } \\
\text { Involving } \\
\text { Humans as } \\
\text { Research } \\
\text { Participants }\end{array}$ & 2007 & $\begin{array}{l}\text { Ugandan National } \\
\text { Council for Science } \\
\text { and Technology } \\
\text { http://www.uncst. } \\
\text { go.ug }\end{array}$ & $\begin{array}{l}\text { Section } 9 \text { of the } \\
\text { guidelines concerns } \\
\text { vulnerable groups and } \\
\text { their protection }\end{array}$ & $\begin{array}{l}\text { Yes, subsection } 9.8 \text { of } \\
\text { the guidelines makes } \\
\text { mention that there } \\
\text { must be adequate } \\
\text { assurance that a soldier's } \\
\text { agreement or refusal to } \\
\text { participate in a research } \\
\text { project is not considered } \\
\text { in promotion, salary, or } \\
\text { career decisions }\end{array}$ & None \\
\hline 2. & $\begin{array}{l}\text { The National } \\
\text { Code for } \\
\text { Health } \\
\text { Research } \\
\text { Ethics for } \\
\text { Nigeria }\end{array}$ & 2006 & $\begin{array}{l}\text { National Health } \\
\text { Research Ethics } \\
\text { Committee of } \\
\text { Nigeria http:// } \\
\text { www.nhrec.net }\end{array}$ & $\begin{array}{l}\text { There are no sections that } \\
\text { refer specifically to the } \\
\text { military }\end{array}$ & No specific issues & None \\
\hline 3. & $\begin{array}{l}\text { Guidelines } \\
\text { on Ethics } \\
\text { for Medical } \\
\text { Research } \\
\text { in SA }\end{array}$ & 2000 & $\begin{array}{l}\text { The Medical } \\
\text { Research Council of } \\
\text { South Africa http:// } \\
\text { www.sahealthinfo. } \\
\text { org/ethics/ethics. } \\
\text { htm }\end{array}$ & $\begin{array}{l}\text { There are no sections that } \\
\text { refer specifically to the } \\
\text { military }\end{array}$ & No specific issues & None \\
\hline 4. & $\begin{array}{l}\text { Guidelines } \\
\text { on Ethics } \\
\text { for Health } \\
\text { Research in } \\
\text { Tanzania }\end{array}$ & 2001 & $\begin{array}{l}\text { Tanzania National } \\
\text { Health research } \\
\text { Forum https:// } \\
\text { webapps.sph. } \\
\text { harvard.edu/live/ } \\
\text { gremap/files/ } \\
\text { tz_health_research_ } \\
\text { ethics.pdf }\end{array}$ & $\begin{array}{l}\text { There are no sections that } \\
\text { refer specifically to the } \\
\text { military }\end{array}$ & No specific issues & None \\
\hline 5. & $\begin{array}{l}\text { Guidelines } \\
\text { for Health } \\
\text { Research in } \\
\text { Zimbabwe }\end{array}$ & 2004 & $\begin{array}{l}\text { The Medical } \\
\text { Research Council } \\
\text { of Zimbabwe } \\
\text { http://www.mrcz. } \\
\text { org.zw-docs }\end{array}$ & $\begin{array}{l}\text { There are no sections that } \\
\text { refer specifically to the } \\
\text { military }\end{array}$ & No specific issues & $\begin{array}{l}\text { Yes, Zimbabwe } \\
\text { Defence Forces } \\
\text { Health Services } \\
\text { Research } \\
\text { Guidelines }\end{array}$ \\
\hline
\end{tabular}


National Guidelines for Research Involving Humans as Research Participants was prepared by the Ugandan National Council for Science and Technology in March 2007. ${ }^{[12]}$ Section 9 of the guideline concerns the protection of vulnerable groups. The guideline mentions that: 'classes of individuals conventionally considered to be vulnerable are those with limited capacity or freedom to consent or decline consent. ${ }^{\text {[12] }}$ According to these guidelines, such individuals include 'children, mature and emancipated minors, street children, prisoners, the homeless, substance abusers, handicapped (mentally and physically), armed forces, and pregnant women.' ${ }^{\text {[12] }}$ Subsection 9.8 of the guideline is devoted entirely to the armed forces and states that: 'soldiers involved in research may be under constraints because of the conditions of their military service and these constraints could affect their ability to make a voluntary decision regarding their participation in research.'[12] The guideline sets some requirements for research involving soldiers on command, such as the condition that a soldier's agreement or refusal to participate in a research project will not be considered in promotion, salary, or career decisions. For example, a field commander cannot refuse to promote a soldier simply because he refused to participate in an HIV sentinel survey study. The Ugandan guidelines directly promote the ethical conduct of health research involving soldiers in Uganda. It addresses all the four topics that we set forth for use in the review of all the African national guidelines selected and speaks specifically to the review of projects, benefits in research, informed consent of soldiers, promotion, pay and career opportunities.

In Nigeria, the National Code for Health Research Ethics was created in 2006 by the National Health Research Ethics Committee of Nigeria. ${ }^{[13]}$ This document requires that institutions must have a registered health research ethics committee to conduct health research. However, the code does not define 'institution', and it is therefore unclear whether the Nigerian military would require its own research ethics committee. There are no sections of the Nigerian code that refer specifically to the military (Table 3 ). The code does not address any of the four topics used in this review.

The Guidelines on Ethics for Medical Research was created by the Medical Research Council (MRC) of SA in 1977 and amended as the fourth edition in 2000. ${ }^{[14]}$ There are no sections that specifically discuss the military, but section seven covers 'vulnerable communities' (Table 3). The MRC also recognises that SA is home to a number of vulnerable communities and demands that particular caution be exercised before involving these communities in research. The vulnerability section does not mention military or hierarchical institutions and does not address any of the topics used in this review.

The Guidelines on Ethics for Health Research in Tanzania was prepared by the National Health Research Ethics Committee of Tanzania in 2001. ${ }^{[15]}$ The guidelines also do not address the topics set aside for this review and do not specifically reference the military (Table 3). Furthermore, section 3.6, which describes 'consent from vulnerable groups in the society', does not mention soldiers as a vulnerable group. ${ }^{[15]}$

The guideline entitled 'Conducting Health Research in Zimbabwe: What Researchers Need to Know' was prepared by the Medical Research Council of Zimbabwe (MRCZ) in 2004. ${ }^{[16]}$ Again, it does not address any of the topics and there are no specific sections regarding the military (Table 3). However, there are military-specific guidelines for the Zimbabwe Defence Forces Health Services Research.

\section{Discussion}

The military is an arena where systemic and institutional norms may conflict with widely assumed principles of research ethics. When an individual joins the military, he or she incurs unique obligations to the country and fellow colleagues. He or she 'agrees' to subordinate their autonomy for the sake of accomplishing the military mission. Soldiers therefore often have diminished autonomy because, by the nature of their profession, some of their civil and political rights are curtailed or significantly restricted for the sake of producing a reliable and effective national defence force. Additionally, militaries sometimes limit soldiers' autonomy to ensure that their behaviour does not harm others or the organisation itself. ${ }^{[5]}$ The hierarchical structure of the military, combined with a prevailing philosophy of sacrifice and obedience, tends to orient military personnel away from individual autonomy and toward the common good. By contrast, in civil society, potential research participants are typically less restricted in their ability to balance individual preferences against the common good. The concern from an ethics point of view is that military researchers are not provided with adequate tools, training, and the authority to ensure voluntary informed participation in research. They are typically not adequately equipped to de-link potential military research participants from an environment that feverishly controls decision-making processes. Without adequate guidance, military health professionals will struggle to manage the tension between definite obligations to respect autonomy, and larger duties to satisfy the legitimate goals of the military. ${ }^{[5]}$

In settings where collaborative military research agreements are standard practice, it is critically important to examine the availability of ethics guidance for military health researchers. Several international research ethics guidelines have been developed since the 'Doctors' Trial' at Nuremberg. ${ }^{[17]}$ Some militaries in developed countries, such as the US, have established their own ethics guidelines to regulate the conduct of human subject research within the military. ${ }^{[18]}$ In the absence of military-specific research ethics guidelines, militaries may use either national guidelines, when available, or rely on international guidelines with the assumption that external collaborators will extend their own protective practices to the local military populations in any collaborative research.

This review of selected guidelines indicates that there is a need for more definite research ethics guidelines for militaries, particularly in sub-Saharan Africa, as many prevailing international and African guidelines have not adequately addressed this population. Only one of the five international guidelines reviewed here, namely CIOMS, specifically mentions the armed forces. However, despite its reference to military personnel, the CIOMS guidelines do not explain in detail how military health researchers can effectively manage important issues such as informed consent in the military context, payment of active duty military personnel for participation in research, and the relationship between commanders and subordinates during research.

Similarly, of five national African guidelines reviewed, the Ugandan national guideline was the only one that specifically addressed the armed forces, providing direct protections for military health research participants. It highlights the fact that potentially the fear of retaliation from senior members of the military could unduly influence the willingness of some personnel to volunteer or participate in research. However, again, other issues such as the payment of 
active duty military personnel during research are not addressed more generally and still need to be examined in most of the already existing guidelines.

\section{Conclusions}

International research ethics guidelines have progressed over time to better accommodate health research among civilian populations, yet clear and specific guidance for the military is still largely lacking across most of Africa. Military personnel are called upon to serve with honour, to the point of possibly sacrificing their lives for their country. Where such willingness to sacrifice is everpresent, greater clarification is essential to distinguish a soldier's duties and obligations from their rights when presented with health and research decisions. While gathering information on military research practices may be a difficult task, future research could focus on interviewing military health researchers and participants to add an empirical basis to the discourse. Furthermore, since most African militaries are likely to draw inspiration from international guidelines, it would be appropriate for soldiers to be included in working groups or panels during future revisions of international guidelines. The participation of military representatives at international ethics workshops and conferences would also be advantageous. Finally, national and international communities should discuss whether general research ethics guidelines are well-suited to guide research with military populations. Militaryspecific human subjects' research guidelines may be better able to reflect the complex nature of the military environment while simultaneously complying with international norms of research ethics.

Competing interests. The authors declare that they have no competing interests.

Authors' contributions. J Nwobegahay designed the research proposal, selected and reviewed the guidelines, and generated the manuscript. J Ali analysed and revised the manuscript. D Ter Goon analysed and revised the manuscript. A A Hyder participated in the conception, review of the guidelines and revision of the manuscript.

Acknowledgements. This work was supported by the Fogarty International Center and National Institute of Allergy and Infectious Diseases of the National Institutes of Health under Award Number R25 TW 001604. The content is solely the responsibility of the authors and does not necessarily represent the official views of the National Institutes of Health.

\section{References}

1. Schwerin M. Health Surveillance Research in Foreign Military Populations. Atlanta: RTI International, 2007: 1-2. http://rti.org/brochures/dhapp_hivsurveillance.pdf (accesssed 21 May 2015)

2. Republic of South Africa. South African Military Health Service: Project PHIDISA. SAMHS info. Bulletin 2007; No. 05/07.

3. Sidel VW, Levy BS. Military Medical Ethics. Physician-Soldier: A moral dilemma? Vol. 2; Chapter 11. Washington DC: Walter Reed Army Medical Center and Bordon Institute 2003:293-312.

4. London L, Rubenstein LS, Baldwin-Ragaven L, van Es A. Dual loyalty in Military Medicine. Dual loyalty among military health professionals: Human rights and ethics in times of armed conflict. Cambridge: Q Health C Ethics 2006;15(4):381-391

5. Visser LS. Military Medical Ethics. The soldier and autonomy. In. Beam TE, Spracino IR, eds. Vol. 1, Chapter 9. Falls Church, VA; Office of the Surgeon General 2003:251-266.

6. Trials of War Criminals before the Nuremberg Military Tribunals under Control Council Law No. 10: Vol. 2, Washington, D.C. US Government Printing Office, US Department of Health and Human Services, 1949:181-182.

7. Emanuel EJ, Crouch RA, Arras JD, Moreno JD, Grady C. Ethical and Regulatory Aspects of Clinical Research. Baltimore, MD: The Johns Hopkins University Press; 2003.

8. World Medical Association. Declaration of Helsinki: Ethical Principles for Medica Research Involving Human Subjects. Amended by the $64^{\text {th }}$ WMA General Assembly, Fortaleza, Brazil, 2013.

9. Department of Health, Education, and Welfare, Office of the Secretary Protection of Human Subjects. Belmont Report: Ethical Principles and Guidelines for the Protection of Human Subjects of Research. Report of the National Committee for the Protection of Human Subjects of Biomedical and Behavioral Research. DHEW Publication No. (OS) 78-0013 and No. (OS) 78-0014. Washington DC: Department of Health, Education and Welfare, 1979:1-9.

10. World Health Organization: Operational Guidelines for Ethics Committees that review Biomedical Research. Geneva: World Health Organization, 2000. http://irb.sinica.edu. tw/doc/regulation/Operational\%20Guidelines\%20for\%20Ethics\%20Committees\%20 That\%20Review\%20Biomedical\%20Research.pdf (accessed 20 September 2015).

11. Council for International Organizations of Medical Sciences (CIOMS) in Collaboration with the World Health Organization (WHO). International Ethical Guidelines for Biomedical Research involving Human subjects. Geneva: CIOMS, WHO, 2002: 1-64. http://www.recerca.uab.es/ceeah/docs/CIOMS.pdf (accessed 21 May 2015).

12. Ugandan National Council for Science and Technology. National Guidelines for Research involving Humans as Research Participants. Uganda: Ugandan National Council for Science and Technology, 2007:1-61.

13. National Health Research Ethics Committee of Nigeria. The National Code for Health Research Ethics for Nigeria. Nigeria: National Health Research Ethics Committee, 2006:1-45

14. The Medical Research Council of South Africa. Ethics for Medical Research in South Africa. General Principles. 4th ed. Parow: MRC, 2000:1-97.

15. Tanzania National Health Research Forum. Guidelines on Ethics for Health Research in Tanzania. Dar es Salaam: Tanzania National Health Research Forum, 2001:1-61.

16. The Medical Research Council of Zimbabwe. Guidelines for Health Research in Zimbabwe. Harare: Medical Research Council of Zimbabwe, 2004:1-22.

17. Faden $\mathrm{R}$, Lederer SE, Moreno JD. US medical researchers, the Nuremberg Doctors trial, and the Nuremberg Code. A review of findings of the Advisory Committee on Human Radiation Experiments. JAMA 1996;276(20):1667-1671. [http:// dx.doi:10.1001/jama.1996.03540200053031]

18. US Army Medical Research. Guidelines for Investigators: Requirements for U.S. Army Medical Research and Materiel Command (USAMRMC) Headquarters Review and Approval of Research Involving Human Volunteers, Human Anatomical Substances, and/or Human Data; Maryland: US Army Medical Research and Materiel Command, 2007:10 -100. 